\title{
GUAVA LEAVES, CORN COBS, AND MANGOSTEEN PEELS AS ANTIOXIDANTS AND NATIONAL STANDARDIZED NATURAL PRESERVATIVES FOR COCONUT BROWN SUGAR
}

\section{ADITYA PRATAMA PUTRA, KINTAN NUR ROMADHONA, ROSIANA SOFIA ANGGRAENI, AI RIAN JULYANTI, RETNO FITRI WIDIASTUTI, DINIATIK*}

Department of Pharmaceutical Biology, Faculty of Pharmacy, Universitas Muhammadiyah Purwokerto, JL Raya Dukuh Waluh Purwokerto, Central Java 53182, Indonesia. Email: diniatik@yahoo.com.au

Received: 19 August 2018, Revised and Accepted: 04 July 2019

ABSTRACT

Objective: Below standard brown sugar is a sugar that cannot be made or resembles dodol (a traditional and sticky confection) because the sap is damaged. Although the sap is made into brown sugar, the product will not last long and become soft-textured sugar. The aim of this research is to prevent below standard sap and produces coconut sugar in accordance with Indonesian National Standard (SNI) using natural preservatives were formulated from guava leaves, corn cobs, and mangosteen peels.

Methods: The formulation of guava leaves, corn cobs, and mangosteen peels was designed through several stages by testing the composition of the materials. The first step was measuring the $\mathrm{pH}$ value of each material with concentration $4.5 \%$, which were $4.5 \mathrm{~g}$ per material and it was compared to the composition of the formula after the concentration of each material was combined to get the basis $\mathrm{pH}$. The second step was formulation to get the natural preservatives by applying the formulas on the tap process of sap until the manufacturing process to get the coconut sugar. Quality of coconut sugar was conducted SNI 01-3743-1995 which included oven method for testing water content and insoluble parts, Luff schoorl method for reducing sugar content and sucrose, and atomic absorption spectroscopy method for testing the contamination of $\mathrm{Cu}$ metal.

Results: Guava leaves, corn cobs, and mangosteen peels with each material 4.5\% were the optimal concentrations as natural preservatives to inhibit fermentation process of sap. Coconut sugars were obtained using these natural preservatives. Coconut sugar that obtained had the moisture content was $0.2402 \%$, the ash content was $1.3 \%$, reducing sugar content was $0.39 \%$, the sucrose level was $69.99 \%$, and the metal contamination was $0.201 \mathrm{mg} / \mathrm{kg} \mathrm{Cu}$. While the results of organoleptic tests indicated the brownish-yellow sugar, a typical sweet taste of sugar, and the normal smell of coconut sugar. All of the coconut sugar properties were meet with SNI.

Conclusion: Guava leaves, corn cobs, and mangosteen peels were effective as natural preservatives and antioxidants to produce the best quality of coconut sugar according to the SNI.

Keywords: Guava leaves, Corn cobs, Mangosteen peels, Preservatives, Coconut sugar.

(C) 2019 The Authors. Published by Innovare Academic Sciences Pvt Ltd. This is an open access article under the CC BY license (http://creativecommons. org/licenses/by/4. 0/) DOI: http://dx.doi.org/10.22159/ajpcr.2019.v12i9.29216

\section{INTRODUCTION}

Brown sugar according to Indonesian National Standard (SNI 01-3743-1995) is sugar made from the processing of the sap of palm trees, namely, sugar palm (Arenga pinnata Merr), nipa palm (Nypa fruticans), palmyra palm (Borassus flabellifer Linn), and coconut (Cocos nucifera Linn). Palm trees (A. pinnata (Wurmb) Merr.) are plants native to Southeast Asia and are mostly found in tropical rainforests and dry forests. Almost all parts of the palm tree are useful for various applications [1]. In Indonesia, brown sugar, which is well known as Gula jawa, has a solid form, and its color ranges from reddish-brown to dark brown [2]. The benefit of brown sugar is the content of the glycemic index (GI) of 35, and it is categorized as low $(<55)$. The GI is a number that indicates the potential of increased blood sugar due to carbohydrate consumption. Low GI values can improve blood glucose response. In addition, it can reduce weight, increase the body's sensitivity to insulin, reduce the risk of cardiovascular, and control cholesterol levels. Based on this, consuming brown sugar is good for health [3]. However, there are several identified problems that need attention, including the raw materials mixed with chemicals (sodium bisulfite) so that many farmers are disadvantaged because brown sugar cannot be produced (below standard) [4]. Brown sugar categorized as below standard cannot be produced or resembles dodol (a traditional and sticky confection) because the sap is damaged. Even though the sap can be made into brown sugar, the product will not last long and will become soft textured sugar [5]. Damage can also occur due to an improper dose of preservatives and an unfavorable climate [6]. The tapping process takes a long time, and coconut sap is easily fermented because it contains high sucrose [5]. Sap is greenish brown liquid produced from sugar cane milling. The sap is very easily damaged; thus, it becomes acidic, foamy, and slimy. If the sap is cooked late, usually it will turn into yellow and cloudy as well as has sour taste and strong odor. The condition of the sap will determine the nature and quality of the sugar produced [7]. There are many kinds of damages which can occur to sap, but generally, sap is said to be damaged if the content of sucrose in it is inverted into reducing sugars consisting of glucose and fructose in the same ratio. This sucrose inversion can be caused by the temperature which is too high, the degree of acidity $(\mathrm{pH})$ of the sap which is too low or high, and the activity of microorganisms [2]. The better the quality of the sap, the higher the amount of sucrose. Besides, the brown sugar formed will have a good texture. If sucrose has been inverted, brown sugar will be difficult to harden [8]. According to Marsigit [9],the addition of sodium metabisulfite in the process of boiling the sap (for $10 \mathrm{~min}$ ) can extend the shelf life of the sap to $62 \mathrm{~h}$. It is also known that without the addition of preservatives, the sap can last for $18 \mathrm{~h}$ with the initial condition of the sap, which is not very good with pH 5.5 and high total acid. The use of lime with a concentration of $1000 \mathrm{ppm}$ can preserve the sap up to $78 \mathrm{~h}$, but from an observation, it is not recommended because it damages the bunches of palm sugar. The addition of sodium metabisulfite is an alternative so that sugar is more durable and lighter in color. The results indicated that sodium bisulfite had no significant effect on moisture 
content, ash content, and reducing sugar content. The greater the concentration of sodium bisulfate, the higher the level of red ash. The water content of brown sugar is positively correlated to the texture. If the water content is higher, the brown sugar will get softer. The addition of sodium bisulfite does not give a significant effect on the brightness of brown sugar color which is aimed at the value of $L$ (Lightness) [6]. Based on this fact, although sodium bisulfite is known to maintain the $\mathrm{PH}$ value it increases the amount of water content in the sap so that the brown sugar produced is still in low quality (below standard) [10]. The utilization of mangosteen (Garcinia mangostana L) peel, corn cobs, and guava leaves is still limited to leather tanning, textile coloring, and traditional medicine. Mangosteen peels have been extracted, and it is found that it contains $95 \%$ xanthone including isoflavones, tannins, flavonoids, Vitamin C, phenol, and anthocyanins [11]. Mangosteen peel is known to contain xanthone compounds such as antioxidants, antiproliferative, and antimicrobials which are not found in other fruits. Xanthone compounds include mangostin, mangostenol A, mangostinone A, mangostinone $\mathrm{B}$, trapezifolixanthone, tovophyllin $\mathrm{B}$, alpha-mangostin, beta-mangostin, garcinone $B$, mangostanol, flavonoid epicatechin, and garthanin. The contents make mangosteen peels extract have very strong antioxidants. It is proven in all solvent fractions (methanol, ethanol, and ethyl acetate) have an effective concentration of $50 \%<50$ [12]. The research results indicated that the extract of corn cobs and corn silk has chemical contents such as flavonoids, alkaloids, saponins, tannins, and allantoin [13]. Antioxidants are defined as compounds that can delay, slow down, or inhibit food or drug oxidation reactions. Antioxidants are substances that can protect cells against damage caused by free radicals, namely, reactive oxygen sp. Tannins are used to protect plants from microbes and fungi [14].

\section{METHODS}

This research was held through several stages and using primary and secondary data. Secondary studies were conducted with the study of literature based on Scopus indexed journals with several keywords such as red palm sugar, sap, brown sugar below standard, guava leaves, corn cobs, and mangosteen peels. The primary study was conducted by doing surveys at research partners' location in Cilongok Sub-district, Banyumas Regency, which included the provision of additional materials in the sap when tapped.

Each plant materials guava leaves, corn cobs, and mangosteen peels were collected from Banyumas regency. Each material was grinded to obtain a powder. The powder of guava leaves, corn cob, and mangosteen leaves was formulated as natural preservatives. To find out the number of additional materials used, the additional materials used and the sap tapped were calculated so that the amount of additional material used per liter of the sap was discovered. Besides, $\mathrm{pH}$ measurements were also carried out before and after using the formulation to find out the difference of sap for making coconut brown sugar.

The formulation included drying the guava leaves, corn cobs, and mangosteen peels which aimed to stop the activity of microorganisms, refining the leaves, cobs, and peels to make them into powder to improve the effectiveness of the formula, sieving the powder to homogenize the weight, mixing the three materials, and dissolving them with hot water to $1 \mathrm{l}$. The formula that had been made was stored overnight before being applied.

In the process of making the formula, the equipment used included scales, blenders, knives, and crock/dryer bases, while the materials used were guava leaves, corn cobs, mangosteen peels, quicklime, and water. After that, the formulation of guava leaves, corn cobs, and mangosteen peel was applied by adding one spoonful of the solution that had been left for one night to each container. The quality of the formulation was discovered by testing the content on the results of brown sugar in accordance with SNI 01-3743-1995 standards.

The organoleptic test, including the shape, smell, taste, and color of the sample, was tested in the laboratory. Other tests carried out were water-insoluble parts, moisture content, ash content, reducing sugar content, and sucrose levels with SNI 01-3743-1995 as the reference. The test of the content suitability of brown sugar was conducted at the Laboratory of Pharmacy Biology of the Faculty of Pharmacy, Universitas Muhammadiyah Purwokerto and the Laboratory of Chemical Analysis, Universitas Jenderal Soedirman Purwokerto.

\section{RESULTS AND DISCUSSION}

Haryanti et al. [15] stated that the microbe contaminating sap include Saccharomyces cerevisiae, which can assist hydrolysis reaction of sucrose to reducing sugars. It is found that the addition of the formulation of guava leaves, corn cobs, and mangosteen peels can reduce the hydrolysis reaction due to antioxidant activity in the materials used, this it can make the coconut sugar in accordance with SNI 01-3743-1995. Guava leaves have phenolic compounds and flavonoids with high antioxidant activity. The main active substances in guava leaves are gallic acid, caffeic acid, guaijaverin [16], tannins [17], carotenoids [18], and triterpenoids [19]. In corn, the anthocyanins and phenolic compounds in whole cob section account for $54.6 \%$ and $59.3 \%$, respectively, of the corn [20]. The ferulic acid was the predominant phenolic compound in corn $[21,22]$. The major secondary metabolites of mangosteen have been found to be prenylated xanthone derivatives [23-26]; some members of this compound class isolated from this plant possess antifungal [27], antimicrobial [25], antioxidant [28], and cytotoxic [29] activities. Mangosteen pericarp ethanol extract has a strong potential to reduce weight gain, fat storage, lipid droplets in the liver (obesity), and development of metabolic syndrome in Wistar rats with high-fat diets compared to positive controls using orlistat [30]. Determination of levels of $\alpha$-mangostin from $95 \%$ ethanol extract from mangosteen from four regions of West Java Province, Indonesia, using the high-performance liquid chromatography method was $12.39 \%$ (Subang), 8.30\% (Purwakarta), 6.34\% (Bogor), and $6.70 \%$ (Tasikmalaya) [31]. This means that the levels of $\alpha$-mangostin from mangosteen in West Java are greater than those reported by Zhao et al. [32]. The formulation was designed through several stages by testing the materials to fit $4.5 \%$. The step done was measuring the $\mathrm{pH}$ value of $4.5 \%$ of each material, which is $4.5 \mathrm{~g}$ of each material and compared with the composition of Formula V. The comparison of the $\mathrm{pH}$ and weight of each material (guava leaves, corn cobs, mangosteen peels, and lime) is as follows (Table 1 ).

Based on the above formula composition design, it is found that Formula $\mathrm{V}$ produced an appropriate $\mathrm{pH}$ value to be used as a preservative (Fig. 1). It could prevent brown sugar to be below standard. Hence, the formula used was formula V. One trial was conducted to the design of Formula $\mathrm{V}$ and compared to brown sugar before using Formula $\mathrm{V}$ because the results of test one indicated that the results of formula $\mathrm{V}$ were better than formula I and it was successful to produce brown sugar in accordance with the SNI -01-3743-1995 as follows (Table 2).

The results showed that guava leaves, corn cobs, and mangosteen peels were effective as natural preservatives and antioxidants on the sap. This is proven since the administration of the substance with a concentration of $4.5 \%$ did not give a significant effect on the moisture content of coconut sugar. This type of preservative had effectiveness in inhibiting the damage of the sap; thus, coconut sugar with standardized

Table 1: Comparison of the $\mathrm{pH}$ and weight of guava leaves, corn cobs, mangosteen peels, lime, and combination of each material

\begin{tabular}{llll}
\hline $\begin{array}{l}\text { Formula } \\
\text { Name }\end{array}$ & $\begin{array}{l}\text { Material } \\
\text { name }\end{array}$ & $\begin{array}{l}\text { Material composition } \\
\text { weight } \mathbf{( g )}\end{array}$ & $\mathbf{p H}$ value \\
\hline Formula I & Guava leaves & 4.5 & 5 \\
Formula II & $\begin{array}{l}\text { Mangosteen } \\
\text { peels }\end{array}$ & 4.5 & 5 \\
Formula III & Corn cob & 4.5 & 6 \\
Formula IV & Lime & 2 & 13 \\
Formula V & $\begin{array}{l}\text { Combination of } \\
\text { each material }\end{array}$ & $4.5: 4.5: 4.5: 2$ & 11 \\
& & \\
\hline
\end{tabular}


Table 2: Comparison of brown sugar use Formula V and before using Formula V to accordance with the SNI -01-3743-1995

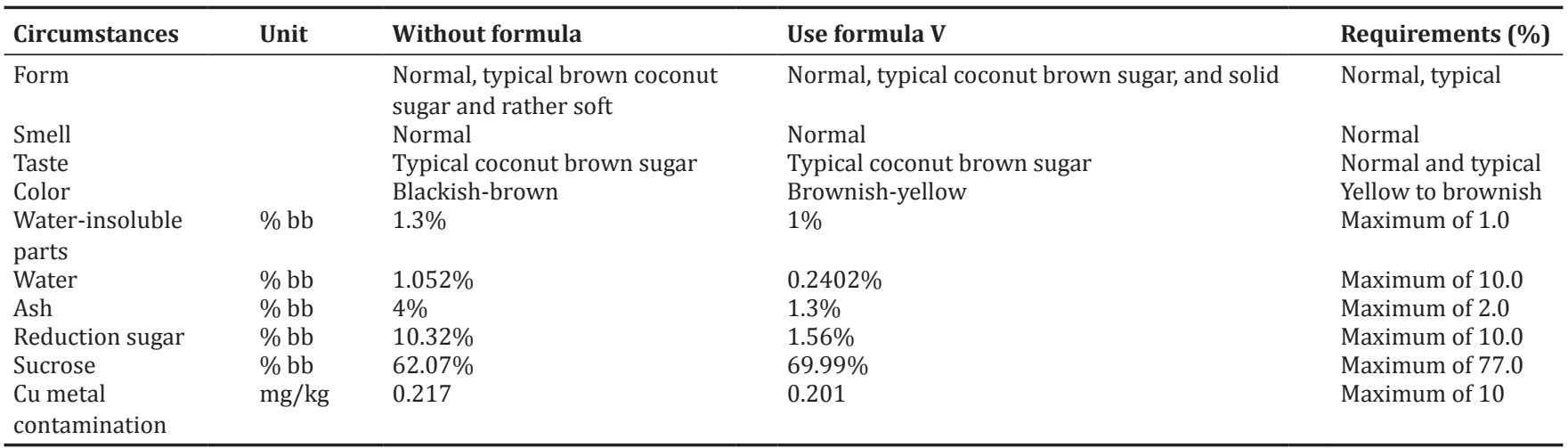
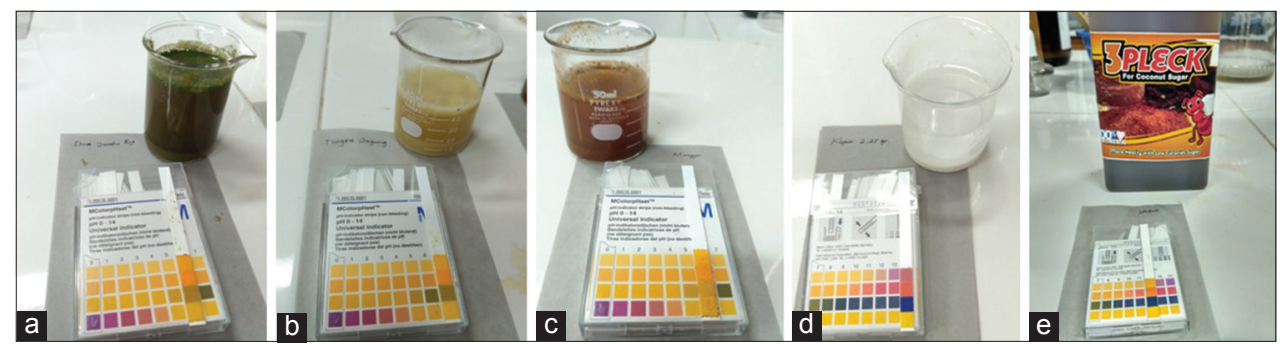

Figure 1: Comparison the pH of (a) guava leaves, (b) corn cobs, (c) mangosteen peels, (d) lime, and (e) combination of each materials

water content could be produced. Sugar water content produced was $0.2402 \%$ so it was effective in inhibiting the deterioration of sap because the sugar water content is still covered by the SNI standard limit of $10 \%$. The water content of a food ingredient greatly influences its storability, because microbes are hampered by the lower water content.

Ash content in sugar is strongly influenced by the mineral content in the sap and the manufacturing process. Ash content of coconut brown sugar was $1.3 \%$ while the maximum ash content, according to SNI 01-7343-1995 is $2 \%$ so that the mangosteen peels preservative with $4.5 \%$ concentration was still within the SNI standard.

The results of the analysis of guava leaves, corn cobs, and mangosteen peels with $4.5 \%$ concentration as natural preservatives and antioxidants indicated that mangosteen peels had the same effectiveness in inhibiting the deterioration of sap when viewed from the parameters of reducing sugar content. In general, the sugar content of coconut sugar reduction had a value of $0.39 \%$. The maximum limit of reducing sugar content, according to SNI-01-7343-1995 is 10\%. All treatments indicated a low reduction in sugar content, which was below the maximum limit of SNI. The lower the value of reducing sugar, the higher the quality of coconut sugar. It will also affect the level of hardness, color, and taste of coconut sugar.

The natural preservatives and antioxidants made of guava leaves, corn cobs, and mangosteen peels with a concentration of $4.5 \%$ also had effectiveness in inhibiting the damage of sap to produce sugar with a sucrose concentration which is in accordance with SNI-01-7343-1995, i.e., $69.99 \%$. The bioactive compounds of the three preservatives were equally effective in inhibiting the fermentation process in the sap so that the total sugar content in the coconut sugar produced still meets the standard. This is due to natural preservatives and antioxidants of guava leaves, corn cobs, and mangosteen peels have bioactive compounds, including tannins which can inhibit sap damage and maintain the $\mathrm{pH}$ of the sap. According to Marsigit [9], the addition of natural preservatives containing tannins can inhibit yeast activity so that it can reduce the hydrolysis reaction of sucrose to reducing sugar.
According to SNI No. 01-3743-1995, the maximum limit of copper metal $(\mathrm{Cu})$ contamination on coconut sugar is $10 \mathrm{mg} / \mathrm{kg}$ while the test results for the use of guava leaves, corn cobs, and mangosteen peels were $0.201 \mathrm{mg} / \mathrm{kg}$. It means that the maximum limit of copper content was still below the safe limit for public consumption since it was far below SNI. Copper metal $(\mathrm{Cu})$ pollution is thought to come from equipment or water used while processing the coconut sugar.

The ash content of natural preservatives and antioxidants of guava leaves, corn cobs, and mangosteen peels $4.5 \%$ was $1.3 \%$. It still meets the SNI sugar quality standard because the maximum content is $2 \%$. The color of coconut sugar ranged from dark brown to brown. According to SNI No. 01-3743-1995, the color of coconut sugar is brownish yellow to brown. The taste of coconut sugar ranged from slightly sweet to sweet. The combination of $4.5 \%$ mangosteen peels treatment gave results that were in accordance with the organoleptic requirements of coconut palm sugar, which is not eliminating the sweetness that exists. Coconut sugar has a unique sweet taste, which is caused by several types of carbohydrate compounds such as sucrose, fructose, and maltose.

The use of natural preservatives can maintain the quality of the sap so that the sugar produced does not taste acidic. This is because natural preservatives contain bioactive compounds that can inhibit sap fermentation caused by enzymatic and microbial activities. Goutara and Wijandi [33] stated that the damaged sap marked by an acidic taste, bubble, and slimy form. The use of natural preservatives and antioxidants of guava leaves, corn cobs, and mangosteen peels produced coconut sugar with typical normal odor, sweet taste, and brownish yellow in accordance with SNI 01-7343-1995.

The use of Formula V, which was natural preservatives and antioxidants made from guava leaves, corn cobs, and mangosteen peels, produced more satisfying and better coconut brown sugar based on SNI-01-7343-1995. It is proven by the results of the tests which had been done, including the water content, ash content, reducing sugar, total sugar content, and $\mathrm{Cu}$ metal contamination. In addition, organoleptic test results indicated brownish-yellow sugar with a typical sweet taste and normal smell. 


\section{CONCLUSION}

Guava leaves, corn cobs, and mangosteen peels with each material concentration $4.5 \%$ are effective as natural preservatives and antioxidants. The natural preservatives and antioxidants produce coconut sugar with the best quality and meet the SNI, with chemical nature, i.e., moisture content $0.2402 \%$, ash content $1.3 \%$, reducing sugar content $0.39 \%$, sucrose level $69.99 \%$, and metal contamination of $\mathrm{Cu} 0.201 \mathrm{mg} / \mathrm{kg}$ and the results of the organoleptic test showed brownish-yellow sugar with typical sweet taste and normal smell. While there are some conditions of coconut brown sugar that is not in accordance with SNI before using Formula V, which are ash content $4 \%$, reducing sugar content $10.32 \%$, and the sucrose level $62.07 \%$. Besides the results, organoleptic test indicates sugar with typical sweet taste and smell but it is blackish brown.

\section{DECLARATION OF CONFLICT OF INTEREST}

The authors declared that they had no conflicts of interest with respect to their authorship or the publication of this article.

\section{ACKNOWLEDGMENT}

We would like to thank the Directorate General of Learning and Student Affairs from Ministry of Research, Technology, and Higher Education Republic of Indonesia for the research funding.

\section{REFERENCES}

1. Elya B, Puspitasari N, Sudarmin AC. Antioxidant activity and inhibition of lipoxygenase activity ethanol extract of endosperm Arenga pinnata (Wurmb) Merr. Asian J Pharm Clin Res 2017;10:76-80.

2. Sardjono, Dachlan MA. The research of fermentation prevention on the tapping of palm sap as raw material to make sugar. J Warta Ind Hasil Pertanian Bogor 1988;5:55-8.

3. Tegar EP. The Evaluation of Diversity and the Deviation of Granule Sugar Quality at Coconut Sugar Home Industry Area in Banyumas Regency. Undergraduate Thesis. Faculty of Agriculture, Universitas Jenderal Soedirman. Indonesia: 2010.

4. Adisatrya A, Achmad H. The Policy of Banyumas Regency Government in the Development of Coconut Sugar Small Industry. Banyumas: National Workshop on the Development of Coconut Sugar and Palm Sugar; 2015.

5. AGUS. Questions and Answers to Brown Sugar Collectors in Lehan Village. Undergraduate Thesis. Faculty of Agriculture. Universitas Lampung. Indonesia: AGUS; 2013.

6. Sulistyaningrum A, Yanto T, Naufalin R, Rifda N, Tri Y, Anna S. The effect of types and natural preservative concentration on the quality of coconut sugar. J Pertanian Pasca Panen 2015;12:137-46.

7. Pratama F, Susanto WH, Purwantiningrum I. "Making coconut sugar from natural fermented nira (study of the effect of anti inversion and sodium metabisulfit concentration. J Pangan Agro Ind 2015;3:1272-82.

8. Fernando L. Addition Of Sucrose in Making Crystal Coconut Sugar. Undergraduate Thesis. Faculty of Agriculture. Universitas Lampung. Lampung; 2014.

9. Marsigit W. Determine The effect of food additive application on the quality of palm sugar were produced in several production centers in Bengkulu. Res J UNIB 2005;11:42-8

10. Aryati A. The Effect of Coating Method and Storage Time on Water Content, Texture, and Appearance of Coconut Sugar. Research Report. Universitas Lampung. Lampung; 2005.

11. Tukiran S, Hidayati N. UJI awal fitokimia ekstrak kulit buah manggis. Vol. 1. Yogyakarta: Pros Semin Nas Kim; 2011. p. 3-4.

12. Miryanti YA, Sapei L, Budiono K, Indra S. Antioxidant extraction of mangosteen peels (Garcinia mangostana L.). Res Rep Eng Sci 2011;2.
13. Yosmar R, Arifin H, Mustika R. Effect of Corn Ethanol Extract (Zea mays L) on Cholesterol Levels of Male White Mice Hypercholesterol. Pros. Semin. Nas. dan Work. "Perkembangan Terkini Sains Farm. dan Kl inik IV; 2014. p. 96-104.

14. Achyar AI, Marta H, Dipa D, Padjadjaran U, Anggaran T. Study of Antioxidant Activity Of Manggis Skin Extract (Garcinia mangostana L) In The Framework Of Utilizing Manggis Leather Waste In Puspahiang District, Tasikmalaya Regency," Univ. Stuttgart; 2008.

15. Haryanti P, Karseno, Setyawati R. Application of natural preservatives for coconut made from green betel to physical and chemical properties of coconut sugar. J Pembang Pedesaan 2012;12:106-12.

16. Gutierrez RM, Mitchell S, Solis RV. Psidium guajava: A review of its traditional uses, phytochemistry and pharmacology. J Ethnopharmacol 2008;117:1-27.

17. Okuda T, Yoshida T, Hatano T, Yazaki K, Ikegami Y, Shingu T. Guavins A, C and D, complex tannin from Psidium guajava. Chem Pharm Bull 1987;35:443-6.

18. Mercadante AZ, Steck A, Pfander H. Carotenoids from guava (Psidium guajava L.): Isolation and structure elucidation. J Agric Food Chem 1999; 47:145-51.

19. Shao M, Wang Y, Huang XJ, Fan CL, Zhang QW, Zhang XQ, et al. Four new triterpenoids from the leaves of Psidium guajava. J Asian Nat Prod Res 2012;14:348-54.

20. Cevallos-Casals BA, Cisneros-Zevallos L. Stoichiometric and kinetic studies of phenolic antioxidants from Andean purple corn and redfleshed sweetpotato. J Agric Food Chem 2003;51:3313-9.

21. Del Pozo-Insfran D, Brenes, CH, Saldivar SO, Talcott ST. Polyphenolic and antioxidant content of white and blue corn (Zea mays L.) products. Food Res Int 2006;39:696-703.

22. Montilla EC, Hillebrand S, Antezana A, Winterhalter P. Soluble and bound phenolic compounds in different bolivian purple corn (Zea mays L.) cultivars. J Agric Food Chem 2011;59:7068-74.

23. Mahabusarakam W, Iriyachitra P, Taylor WC. Chemical constituents of Garcinia mangostana. J Nat Prod 1987;50:474-8.

24. Suksamrarn S, Suwannapoch N, Ratananukul P, Aroonlerk N, Suksamrarn A. Xanthones from the green fruit hulls of Garcinia mangostana. J Nat Prod 2002;6 761-63.

25. Suksamrarn S, Suwannapoch N, Phakhodee W, Thanuhiranlert J, Ratananukul P, Chimnoi N, et al. Antimycobacterial activity of prenylated xanthones from the fruits of Garcinia mangostana. Chem Pharm Bull (Tokyo) 2003;51:857-9.

26. Nguyen LH, Venkatraman G, Sim KY, Harrison LJ. Xanthones and benzophenones from Garcinia griffithii and Garcinia mangostana. Phytochemistry 2005;66:1718-23.

27. Gopalakrishnan G, Banumathi B, Suresh G. Evaluation of the antifungal activity of natural xanthones from Garcinia mangostana and their synthetic derivatives. J Nat Prod 1997;60:519-24.

28. Yoshikawa M, Harada E, Miki A, Tsukamoto K, Liang SQ, Yamahara J, et al. Antioxidant constituents from the fruit hulls of mangosteen (Garcinia mangostana) originating in Vietnam. Yakugaku Zasshi 1994;114:129-33.

29. Ho CK, Huang YL, Chen CC. Garcinone E, a xanthone derivative, has potent cytotoxic effect against hepatocellular carcinoma cell lines. Planta Med 2002;68:975-9.

30. Abuzaid AS, Sukandar EY, Kurniati NF, Adyana IK. Prevention of obesity and development of metabolic syndrome by mangosteen (Garcinia mangostana L) pericarp ethanolic extract in male Wistar rats fed with high-fat diet. Int Pharm Pharm J 2016;8:372-8.

31. Muchtaridi M, Suryani D, Qosim WA, Sapterini NY. Quantitatif analysis of $\alpha$ mangostin in mangosteen (Garcinia mangostana L.) pericarp extract from four district of West Java by HPLC method. Int Pharm Pharm J 2016;8:232-3.

32. Zhao Y, Liu J, Lu D, Li P, Zhang L. Determination of alpha mangostin in pericarpium of Garcinia mangostana by RP HPLC-UVD. Med Plant 2010;1:46-7.

33. Goutara, Wijandi T. Dasar-dasar Pengolahan Gula II. Department of Farm Yield Technology. Bogor: Fateta IPB; 1985. 